Journal of Southeast Asian

2019

\title{
Mimicry: A Short Play
}

Diana M. Pho

Independent Scholar, diana.m.pho@gmail.com

Follow this and additional works at: https://docs.lib.purdue.edu/jsaaea

Part of the Asian American Studies Commons, Bilingual, Multilingual, and Multicultural Education Commons, Other Theatre and Performance Studies Commons, and the Playwriting Commons

\section{Recommended Citation}

Pho, Diana M. (2019) "Mimicry: A Short Play," Journal of Southeast Asian American Education and Advancement: Vol. 14 : Iss. 1, Article 10.

DOI: $10.7771 / 2153-8999.1189$

Available at: https://docs.lib.purdue.edu/jsaaea/vol14/iss1/10

This document has been made available through Purdue e-Pubs, a service of the Purdue University Libraries. Please contact epubs@purdue.edu for additional information.

This is an Open Access journal. This means that it uses a funding model that does not charge readers or their institutions for access. Readers may freely read, download, copy, distribute, print, search, or link to the full texts of articles. This journal is covered under the CC BY-NC-ND license. 


\title{
JSAAEA Journal of Southeast Asian American
Education and Advancement
}

Vol. 14 Iss. 1 (2019)

WWW.JSAAEA.org

\section{Creative and Literary Works}

\author{
Mimicry: A Short Play \\ Diana M. Pho \\ Independent Scholar
}

\section{$\underline{\text { Characters }}$}

1 - A scientist conducting an observational study. Thinks she knows everything.

2 - 1's scientific sidekick. Doesn't think she knows everything, but she tries.

Laurel - 22, Southeast Asian-American

Mattie - 22, Southeast Asian-American

Setting: A university outdoor café. A table. Two chairs. Summer time.

LAUREL, 22 and wearing jeans and a nondescript T-shirt, walks onstage. She is carrying a weighty textbook on monarch butterflies. She looks around for someone, but seeing none, sits hesitantly in the chair. After a few moments, she rises from her seat.

She turns, expecting someone there. No one.

Pause. Moves to sit. Then, she turns the other way. No one.

Pause. Moves to sit again. Footsteps. She turns and a bell rings. Freezes.

\footnotetext{
(C)

SDDERIGHISRESERNEDReaders are free to copy, display, and distribute this article, as long as the work is attributed to the author(s) and the Journal of Southeast Asian American Education \& Advancement, it is distributed for non-commercial purposes only, and no alteration or transformation is made in the work. More details of this Creative Commons license are available at http://creativecommons.org/licenses/by-nc-nd/3.0/. All other uses must be approved by the author(s) or JSAAEA. Journal of Southeast Asian American Education \& Advancement, Vol. 14. Iss. 1. (2019) ISSN: 2153-8999
} 
1 and 2 come out wearing masks and lab coats. 1 walks around the table, looking at LAUREL with a puzzled gesture or two. Shrugs. Goes back to 2 and both get into position.

1: Hello everyone. (clears throat) Now that we've gotten your attention, we shall begin our observational study. Clipboard?

2 takes out a clipboard.

1: No. 2 pencils?

2 takes out a fistful of pencils and starts offering them to the audience.

1: Does anyone need a pencil? Anyone? Okay then. (holds out a bell) Let us begin.

They leave. Bell rings. Unfreeze.

LAUREL unfreezes and sits back down.

LAUREL: I never thought I'd be back here. Not here, I mean, I never actually went to this school. The town, yes, I grew up here. But to actually go to this school ... Some colleges you apply to as the safety net, the last choice. If you didn't get into any of the Ivies, this was still a respectable enough of a place. (checks watch) Where is she? She's not supposed to be late, right? Maybe she forgot? Maybe she doesn't want to see me? It has been a long time ... I wonder if she looks different. Maybe I just don't recognize her ...

MATTIE, 22, in a short skirt and tall boots with a low-cut shirt and a black fedora, enters. She seems older than Laurel somehow. Looking around, she suddenly clasps her hands together and points them toward Laurel.

MATTIE: (squeals) Laurel?

LAUREL: Mattie?

MATTIE: Oh my gods! (runs over. LAUREL stands and is nearly bowled over by MATTIE'S $h u g$ ) It's been forever! And I was afraid I wouldn't recognize you!

LAUREL: Me too. You've changed a lot. You have contacts?

MATTIE: Yup.

LAUREL: They're an odd color ...

MATTIE: I like catching people off-guard. Sometimes, people ask if I'm bi.

LAUREL: (off-guard) Bi- 
MATTIE: Biracial. And sometimes, I say yes. Cool, isn't it? (holds her shoulders at arms' length) You look good too.

LAUREL: Thanks.

They sit.

MATTIE: So, what do you think of being back here after, what, seven years?

LAUREL: It's... different. Everything looks familiar, but in a skewed way, as if I dreamt about this place instead of lived in it.

MATTIE: Yeah, I know how that can be. This place isn't very memorable outside of campus.

LAUREL: Makes me feel all nostalgic ... like I'm so old for some reason ... (suddenly) Do you remember middle school? The group we hung out with?

MATTIE: Group?

LAUREL: Yeah, don't you remember?

MATTIE: No. I never really hung out with-

LAUREL: Oh no, I meant Judy Nguyen, Kim Le, Annie Hung, Jessica Chao ... Do you ever talk with them now?

MATTIE: Well... (thinks) Judy went to Dartmouth, Kim went to Brown, Annie got into MIT, and Jessica...I think she went to Emerson.

LAUREL: Jess was always the odd one out.

MATTIE: I don't know whether they're still around for the summer. They could be. Or they could be working ... But how about you? So, you're here on an internship thing, right?

LAUREL: A research program, actually. I'm working on an independent study this summer with my advisor.

MATTIE: Cool. So what are you researching?

LAUREL: He and a couple of other colleagues came here to look at the behavioral effects of cohabitation among monarch and viceroy butterflies. They released a group of 20 monarchs and 5 viceroys into this little greenhouse room they constructed into some imitation forest. It's interesting how they interact.

MATTIE: How would they interact? What do butterflies say to each other? "Hey, bud, get off my stamen. That daisy's mine." 
LAUREL: (a bit offended) It's all subtle, really. At least, that's what the general assumption is. They watch butterflies and take notes. I watch them and type their notes up. Not a glamorous job, but it pays. And by staying with my dad here, I can save on housing costs.

MATTIE: So the divorce ended up having some advantages after all, eh?

LAUREL: Yeah, you can say that. So, anyways, how have you been?

MATTIE: Oh busy, busy. I took a job as a technician-

Bell rings urgently. They freeze. 1 storms on, grabs the book from the table, and flips it open. 2 follows, scribbling rapidly on her clipboard.

1: (to 2) Did you leave this here?

2 doesn't pay attention.

1: Hello? (sticks book in front of 2 's face, much to 2 's surprise) What do you think you are doing?

2 holds arms out in surprise and confusion.

1: (waving book in front of 2's face, as 2 backs away) After seven years of blood, sweat, tears, saliva, phlegm, and other various fluids, will this be our undoing?

2 shakes head emphatically.

1: After all of our time, and all our effort, are you out to ruin us?

2 shakes head even more emphatically.

1: Are you-!

2 cowers.

1: Fine then. (tucks book under arm and drags 2 off stage)

Bell rings. Unfreeze.

LAUREL: Yeah, you can say that. So, anyways, how have you been?

MATTIE: Oh busy, busy. I took a job as a technician at the pharmacy in town.

LAUREL: Nice. How is it? 
MATTIE: Pretty boring. But it pays well.

LAUREL notices that her book is missing.

LAUREL: (startled) Mattie, did I carry a book with me here?

MATTIE: Book?

LAUREL: Yeah, I thought I had it right here on the table ... (looks inside her bag, then gets up) I swear I had it with me.

MATTIE: What was it called?

LAUREL: Oh, it was just something to read during my free time. I took it on loan from the library just now...

MATTIE: Maybe you put it back in your room?

LAUREL: But I swear that I- (stops self) Maybe you're right. (laughs) Something strange has been happening since I got back here.

MATTIE: How so?

LAUREL: Things keep going missing. Or at least I keep thinking that I'm missing things. Like I'd be helping with the research, or be sorting socks, or cooking dinner and suddenly, I'd lose track of whatever I had in my hands. Like time itself just ... jumped.

MATTIE: Maybe it's stress? Or boredom?

LAUREL: Maybe. (uncertainly sits down back in her seat)

MATTIE: What was this book about anyways?

Bell rings courteously. Freeze.

1 goes onstage with LAUREL'S book in hand. 2 follows. 1 stops center stage, adjusts glasses and reads aloud in a pedantic, Russian-accented voice as 2 listens.

1: "The mysteries of mimicry had a special attraction for me. Its phenomena showed an artistic perfection usually associated with man-wrought things. 'Natural selection,' in the Darwinian sense, could not explain the miraculous coincidence of imitative aspect and imitative behavior, carried to a point of mimetic subtlety, exuberance, and luxury far in excess of a predator's power of appreciation." Vladimir Nabokov.

(shuts book smartly) 
2: Who was he?

1: A writer.

2: Never heard of him.

1: He's Russian. He wrote that book-

2: Nabokov?

1: Yes. About the man and the little girl-

2: Never heard of it.

1: You know the girl - Lolita? (gestures suggestively)

2: Oh, that little girl. (repeats gesture) Heard of her.

1: Exactly. He held a certain interest with butterflies, but people know him for Lolita.

2: Well, that just says a lot about Nabokov, doesn't it?

1: (confused) Which does?

2: Was it only a hobby? Collecting them?

1: Little girls?

2: I mean butterflies.

1: Oh that. People say it was. Nabokov, the last of a dying breed of gentlemen-naturalists. (ponders) Or maybe it was just a fetish.

They move to sit at a table upstage with their notes. Bell rings. Unfreeze.

MATTIE: What was in this book anyways?

LAUREL: Oh, it's by Vladimir Nabokov.

MATTIE: Who?

LAUREL: A writer.

MATTIE: Never heard of him.

LAUREL: He's Russian. He wrote that book with the little- 
MATTIE: Ah. That book. I remember.

LAUREL: My boyfriend's crazy over him.

MATTIE: (interested) Boyfriend?

LAUREL: Yeah, here (takes out photo from her purse and shows it to MATTIE)

MATTIE: (beat) So... that's your boyfriend?

LAUREL: Yeah.

MATTIE: He's, um, cute. Where does he go again?

LAUREL: UCLA. He's a poli sci Ph.D candidate.

MATTIE: Nice. How long have you been going out?

LAUREL: It'll be a year next month.

MATTIE: (hesitant, but curious) How'd you meet him?

LAUREL: Friend of a friend. She thought David would like me, and so we set up a blind date. Went out ever since.

MATTIE: Do you ever wonder if it's you he likes, or your looks?

LAUREL: (slightly confused) David says that all those pretty blonde girls look the same to him.

MATTIE: (laughs) True. I used to date a man who was really into Japanese animation. I mean, really. Anime otaku. That's what he called himself. There were pictures of Tokyo all over his walls and those large posters of different anime girls. It was so weird. Too weird. We'd walk down the street and he'd be all like, "You're so kawaii," and practicing his Japanese with me. I took him back home one weekend and we were sitting at the food court in the mall. He was practicing his Japanese, spouting compliments like, "Your eyes are cherry blossoms in the spring." And some lady sitting at the table next to us turned around and said, "That's so cute that you're learning her language!" And she smiled and left.

LAUREL: (unsurely) That is weird.

MATTIE: Isn't it? I mean, it gets annoying. Sometimes, I feel like I'm the only Asian in town, now that everyone's left. (beat) The guy I was dating was pretty weird too. He kept obsessing over my hair. Playing with it. Running his fingers through it.

LAUREL: I don't see anything wrong with that. David does that all the time. 
MATTIE: But not in a normal way, y'know? He would stare at me when I wasn't looking. Not in the lovelorn way, but in that seedy way. It was kind of creepy. (bluntly) He had a lot of hentai hidden in his closet.

LAUREL: Hentai?

MATTIE: Anime porn.

LAUREL: (makes a face) I thought all anime was porn.

MATTIE: (pushes her shoulder) It was disturbing. In some of them, they used tentacles.

LAUREL: Who did?

MATTIE: The octopus.

(Beat. LAUREL is stunned.)

After that, I try to stay away from men with an Asian fetish.

LAUREL: Mattie!

MATTIE: What, Laurel? It's true.

LAUREL: But that sounds so dirty!

MATTIE: C'mon, don't you ever wonder when a white guy hits on you? Does he like you, or does he just like the image of you? Not you, but whatever silvery glow of quiet submission and ancient mystique that they see shining from your almond eyes and pretty moon complexion?

LAUREL: Mattie, you're ridiculous.

MATTIE: Why don't you ever ask your boyfriend that?

LAUREL: You haven't even met him! Anyways, what about us? Were you ever attracted to other Asian guys?

MATTIE: They were never attracted to me.

LAUREL: I mean, what kind of people do you like?

MATTIE: (thinks) Brown hair. Blue eyes. Tall. 
LAUREL: Then what if you're the one with the Caucasian fetish! (sarcastic) Would you adore the way he is, or only the way his pale skin and lanky frame exude visions of rugged individualism and dreams of living in picket-fence suburbia with an SUV in the driveway?

MATTIE: (insulted) Really? It might be different in southern California, Laurel, but growing up in the midst of (tries to think of word, but fails) here, do you think there were a lot of choices? Am I expected to be attracted to people who look like me, or people who are around me?

LAUREL: So you don't think that we're traitors for who we like? What if my boyfriend happens to be Irish? It just happens. I like who I like.

MATTIE: Is your mom okay with that?

LAUREL: She will be.

MATTIE: She doesn't know? It's been a year!

LAUREL: For now, I'm telling her we're just "friends."

MATTIE: Does she believe you?

LAUREL: I am a perfect impression of the ideal daughter. Volunteering at church, active at school, as innocent as she supposedly was at my age.

MATTIE: What was she doing at your age?

LAUREL: Fucking my father.

MATTIE: Which explains the quick wedding.

LAUREL: And the ten years of marriage.

MATTIE: Atonement for their sins?

LAUREL: My grandparents didn't believe in divorce, so it took a long time for my mom to start believing in it too.

MATTIE: Her own personal revelation?

LAUREL: The modern-day salvation. (pause) It's better for her not to worry.

MATTIE: Oh. (pause) Your dad stops by the pharmacy sometimes, by the way. How's staying with him?

LAUREL: Okay, I guess. He leaves the house at 6 to beat the commute. I leave the house at 8 . I get home at 5 , have dinner and go to my room. He comes home at 8 , has dinner, watches TV 
then goes up to his room. We've spoken five sentences to each other in the last three days; it's the best relationship we've had yet.

MATTIE: Claps to that.

LAUREL: It's okay. I end up with a lot of free time on my hands for extra reading on my research.

MATTIE: I never knew you were that interested in butterflies.

LAUREL: Well, they're simply fascinating. I mean, the research I'm focusing on deals with Batesian mimicry. You see, monarchs have a special poison in their bodies which wards off predatory birds. They get this poison from eating milkweed plants.

MATTIE: I see.... (As LAUREL continues, MATTIE smiles and nods, but you can practically see her eyes glaze over.)

1 takes out an enlarged diagram of a monarch butterfly with label and hands it to 2.

LAUREL: The viceroy looks very similar to the monarch butterfly but doesn't contain this same poison. They eat different plants and never acquire this defensive mechanism.

1 takes out a large diagram of the viceroy butterfly and hands it to 2.

LAUREL: Viceroy butterflies mimic monarchs in order to protect themselves.

2 struggles to balance both pictures in her arms, plus labels. The labels all fall to the floor. 1 goes back to her clipboard not noticing.

LAUREL: Birds can't tell the physical differences between the original and the imitation, and so thus, viceroys secure their own survival. Viceroys are natural posers. Most people can't even tell the difference between the fake and the Real McCoy.

2 tries to set the pictures up, but only holds the labels in her hands with a puzzled look on her face. She mimes "Emy, Miny, Mo" with her pointer, but then, an entertaining idea pops into mind instead.

2: $(\operatorname{sings})$

One of these things is not like the others

One of these things just doesn't belong-

1 grabs the pointer from 2.

LAUREL: Mattie? 
MATTIE: Huh?

LAUREL: Well, enough about that. (sheepish) Didn't mean to put you to sleep.

MATTIE: (wakes up) No, I mean, it's really cool.

LAUREL: Yeah, it is. (ponders) Do you think a viceroy ever realizes it's copying another creature? Or does it just flutter about, unaware that its whole life is just a lie in order to survive...?

Pause.

MATTIE: (changing the subject) So, how's Stanford?

LAUREL: Well, it's okay.

MATTIE: Okay, and ...?

LAUREL: Not as hippie-lib as people make it out to be. And hey, in case you were worried, I have a life outside the lab. There's a recreational scuba club and I'm advising the undergrads in the ASA.

MATTIE: Oh.

LAUREL: What do you mean, oh?

MATTIE: Are you really into stuff like that?

LAUREL: I go scuba diving every month, if that's what you mean.

MATTIE: The "auntie" grad student. Mentoring the youth. It's cute. (laughs but LAUREL doesn't get it) I hate it when the international students get all clingy, anyway. It's awkward. (avoids LAUREL'S expression as she starts to backtrack) You know, they're nice, they're super nice, but there's a sort of gap between us. Like I somehow Don't Get It. They all know each other in some deep way whereas I can only scratch the surface. They got a sort of je ne sais pas. And I just have the pas.

LAUREL: You mean rien?

MATTIE: I meant, oh ... nothing. I tell them I'm adopted and they leave me alone enough.

LAUREL: You're not adopted.

MATTIE: I might as well be, since it's a better excuse than being called a banana by your ASA goupies. (laughs) Not that it matters. 
LAUREL: It's not a clique, it a very strong empowerment group. And don't put down these kids; they've done a lot of good for Stanford's community-

MATTIE: Okay, okay, sorry...But didn't you feel weird when you first moved to Cali? I mean, we both grew up in New England whitesville-

LAUREL: At first. I felt awkward, because you got so used to standing out in this place. It's different out west. There's this big youth group I got involved in $7^{\text {th }}$ grade-

MATTIE: Like Chinese school?

LAUREL: Sort of.

MATTIE: We used to make fun of the kids who went to Chinese school! Not like they had a Vietnamese school for us.

LAUREL: Well, everyone gets involved where I'm from. It's the thing to do. You organize your festivals, you make sure the lion dancers come for New Year's, you arrange lectures about the growing dangers of communism to economic globalization, you sell egg rolls during finals ... It's what I do, and when I do it, I feel like I finally fit in somewhere.

MATTIE: That's nice that you found all of that ... Must be a lot of fun.

LAUREL: Yeah.

MATTIE: (sharply) Maybe that's why you never bothered to text back after the move.

LAUREL: What do you mean?

MATTIE: Maybe because you felt satisfied in Cali. Finally, a bigger clique you belong in.

LAUREL: Mattie?

MATTIE: (finally, all the cheer snaps) Look, I'm tired of playing this game, Laurel. Why did you ask to meet up anyways? I've been trying to figure you out this whole time. We hadn't talked to each other since $5^{\text {th }}$ grade, when you left me to hang out with Judy, Kim, Annie and Jessica. That clique. And you don't even talk to them anymore either? What happened - you found friends who are even more Asian to make you happy?

LAUREL: (surprised) You're just trying to make me mad, aren't you? You were always trying to make me mad at everything. You never appreciated yourself or anything else.

MATTIE: What do you mean?

LAUREL: What is wrong with you, Mattie? The whole world isn't a conspiracy out to get you, but you thought it was. "Why wouldn't they hang out with me?" "They must be too cliquey. 
Anyways, they only hang around with other people like themselves." Well, I got tired of your "rebel without a cause" attitude. I decided to actually try to be happy with myself, instead.

MATTIE: Happy by acting like a little peon! You did whatever Judy or Kim or Annie or Jessica did because you felt "welcomed" by tagging along with them! I wasn't a rebel; I was just different, and those girls always picked on me for it. (gets up from chair) Why couldn't we have stayed friends? Something went wrong with you, Laurel. I was never good enough for you.

LAUREL: What went wrong with me? (sweeps hand at MATTIE) You're the one throwing a pity party over middle school. (gets up from chair) I just wanted to reconnect.

MATTIE: Why? To hold up that perfect illusion of yourself? The ideal Asian who reunites with her brethern.

LAUREL: At least I'm not a bitter bitch.

MATTIE: Better than a "more Viet-than-thou" bitch.

Bell rings. They freeze in an angry tableau.

1: (runs on stage with book and clipboard in hand) Wait I second! I got it!

2: What, what?

1: I knew there was a misconception about this all along!

2: There was?

1: YES!

(gives MATTIE the book, and puts the hat on LAUREL)

2: I don't get it. You mean, was she- and she-

1: It only makes sense!

2: How do you know? She's not going to Stanford! She's not the one on summer research! David isn't her boyfriend!

1: How do you know?

2: (points to MATTIE) But she's the viceroy!

1: How do you know? 
2 switches the book and the hat to their former positions. Contemplates. Switches again. Contemplates some more.

2: (unsurely) Actually, it's hard for me to tell the difference anymore ...

1: (worried) Shush! Oh, you confused me now!

LAUREL and MATTIE unfreeze. They start to yell at each other again, but notice 1 and 2 standing in front of them, and are taken back. As 1 and 2 still argue, both watch in shock.

1: Mattie's the viceroy then! Trapped in a small town, with no one to relate to, trying to pretend that she's someone she obviously is not. Mattie longs for a chance for understanding, but, locked into an isolated community, she is forced to adapt to the ways of the local species-

2: No, Laurel is! Removed from her native home, Laurel is plunked into a new and alien setting where she searches to find herself within the established society. Living in SoCal, trying to fit in with the other monarchs, do monarch things, take pride in being a monarch and entrenching herself into the monarchy... (beat) You know, don't you ever get that funny feeling that after you repeat the same word over and over again, it loses its meaning?

LAUREL and MATTIE exchange mischievous looks. Then LAUREL creeps up behind 1, while MATTIE does the same with 2.

1: But what if Laurel is?

2: But what if Laurel is?

1: Or what if Mattie is?

2: Or what if Mattie is?

1: What if they both are?

2: (sudden realization dawns) What if there is no such thing as a monarch butterfly? Or a viceroy?

1: (catching on) But every one lives to fool the birds ...

2: Or to fool themselves ...

LAUREL and MATTIE: Or to fool you!

1 and 2 turn around, both confronted by LAUREL and MATTIE respectively.

LAUREL: (enraged) What do you think you're trying to do? 
MATTIE: Who the hell are you?

1: (meekly) We're ... we're scientists.

2 nods frantically.

LAUREL: The kind of scientists who stalk other people, huh?

1: (apologetically) We were only doing observations! We had a scale of measurement to fulfill! I know, I know, after awhile, it might seem a bit ... Intruding, but that's what we do. We watch and take notes and then type them up. It's all very interesting...

MATTIE: (disgusted) You can't talk about human beings, individual human beings, as if they were nothing more than insects! (pushes 2. LAUREL pushes 1.) Do you think I can be divided into a certain category by how I act or what I wear? (Both push again.)

LAUREL: Do you think you have the right to judge me without knowing who I am, or how I feel? (Both push again. 1 and 2 are now back-to-back against each other and shaking visibly)

MATTIE: I am who I am.

1: (pure frustration) But what is that-??

Pause. Sudden revelation between LAUREL and MATTIE.

MATTIE: I am me. I like short skirts and pretty girls and lanky boys. I'm obsessed with Project Runway and play rugby. But that doesn't make me a misguided Asian or a white wannabe.

LAUREL: I take ribbon dancing lessons and I scuba dive. I like my mother's cooking and want to study insects, not pre-med. But that does not make me any different or the same as her.

MATTIE: So deal with it.

LAUREL brings the book down on 1's head and MATTIE does the same with her hat to 2. 1 falls flat, unconscious, and scatters her notes everywhere. 2 stumbles about making muffled sounds as she struggles to get the hat off her head. MATTIE grabs LAUREL'S book and whacks 2 on the head with it. 2 trips over 1's crumpled form and falls down, knocking herself out cold.

LAUREL and MATTIE wipe the dust from their hands. MATTIE hands the book back.

MATTIE: I always knew bio textbooks were useful for some reason. (crosses her arms and look down at 1 and 2) Scientists.

LAUREL: They observe and assume, but never bother to ask.

MATTIE: (picks up one of 1 's fallen notes) But at least they take good notes. 
LAUREL: (reads) "The Difference between Butterflies." "Monarchs and Viceroys: Who is Imitating Who?" These are my notes, Mattie! Who is this person and why does she have copies of my research notes? But there's more here ....!

As LAUREL continues to read, MATTIE picks up 2's mask, then searches through 2's pockets, but finding nothing of interest, takes her lab coat instead and puts it on.

LAUREL: "Latest studies show that viceroys may not be mimicking after all. According to a recent study, viceroys contain the same poison that monarch butterflies do, although they do not feed on the same milkweed plant. Viceroy butterflies have evolved their own method of defense, questioning the long-standing theory that viceroys had ever used mimicry at all." If both monarchs and viceroys are evolving the same abilities ... You can't tell the difference between them anymore! Don't you understand? Mattie, don't you realize what this means?

MATTIE, with the mask on now as well, shakes her head. Offers LAUREL I's lab coat and mask.

LAUREL: (putting them on) This is the greatest breakthrough in the lepidopteron community in the last century! No one is "the fake". If we look through this more carefully- (takes 1's clipboard from the ground and starts writing) -this could change the entire way butterflies live and communicate!

MATTIE rolls her eyes and shrugs as if to say, "Well, if you find it interesting ..."

LAUREL: This is more than interesting. Think about it: there is no such thing as mimicry! It's revolutionary. (beckons MATTIE to her side. MATTIE steps over 2's body and looks over LAUREL'S shoulder)

Clipboard?

MATTIE picks up 2's clipboard.

LAUREL: No. 2 pencils?

MATTIE takes out a fistful of pencils from her pocket and starts offering them to the audience.

LAUREL: Does anyone need a pencil? Anyone? Okay then. (takes out bell from 1's pocket) Let us begin again.

Bell rings.

BLACKOUT. 


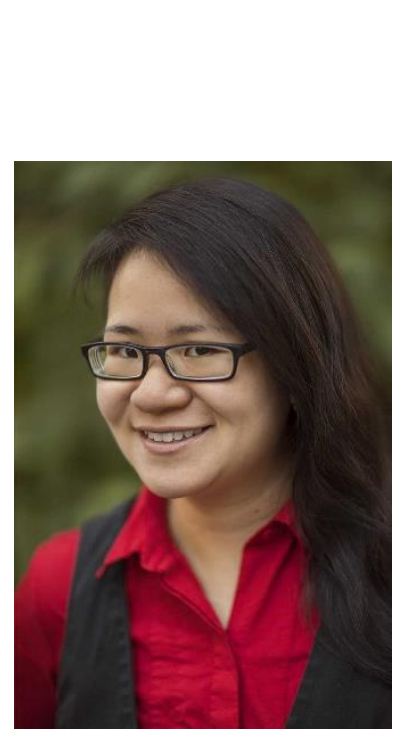

About the Author

Power of Style. She currently lives and works in New York City.

Diana M. Pho, is a queer Vietnamese-American independent scholar, playwright, and book editor. Pho has a double Bachelor's degree in English and Russian Literature from Mount Holyoke College and a Master's in Performance Studies from New York University. In 2018, Pho was nominated for Best Editor, Long-Form in the Hugo Awards, one of the most prestigious honors in the field. Novels she has edited have won the Thriller Award and Ditmar Award, and become finalists for the Nebula Award, Lambda Literary Award, Shirley Jackson Award, and Andre Norton Award for Young Adult. Academic publications include a forthcoming article in the Journal of Neo-Victorian Studies, and book chapters in Like Clockwork: Steampunk Pasts, Presents, and Futures, Steaming into a Victorian Future, and Fashion Talks: Undressing the Power of Style. She currently lives and works in New York City. 


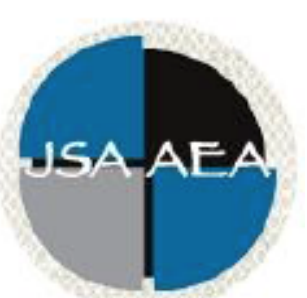

Vol.14 Iss.1 (2019)

\section{Journal of Southeast Asian American Education and Advancement}

\author{
Editor \\ Dr. Wayne E. Wright \\ Purdue University \\ Associate Editors \\ Dr. Chhany Sak-Humphry \\ University of Hawaii at Manoa \\ Dr. Phitsamay Sychitkokhong Uy \\ University of Massachusetts, Lowell \\ Book Review Editor \\ Dr. Vichet Chhuon \\ University of Minnesota \\ Creative Works Editor \\ Bryan Thao Worra \\ Lao Assistance Center \\ Journal Manager \\ Fang Gao \\ Purdue University
}

Editorial Review Board

\author{
Dr. Steve Arounsack \\ California State University, Stanislaus \\ Dr. Sovicheth Boun \\ Salem State University \\ Dr. Virak Chan \\ Purdue University \\ Dr. Loan Dao \\ University of Massachusetts Boston
}

\author{
Dr. Carl L. Bankston III \\ Tulane University \\ Dr. Phala Chea \\ Lowell Public Schools \\ Dr. George Chigas \\ University of Massachusetts, Lowell \\ Dr. Hien Duc Do \\ San Jose State University
}


Dr. Changming Duan

University of Missouri-Kansas City

Dr. Sothy Eng

Lehigh University

Dr. Vincent K. Her

University of Wisconsin, Eau Claire

Dr. Peter Nien-Chu Kiang

University of Massachusetts, Boston

Dr. Kevin K. Kumashiro

University of Illinois, Chicago

Dr. Ha Lam

Eastern Mennonite University

Dr. Jonathan H. X. Lee

San Francisco State University

Dr. Monirith Ly

Royal University of Phnom Penh

Dr. Bic Ngo

University of Minnesota

Dr. Leakhena Nou

California State University, Long Beach

Dr. Mark Pfeifer

SUNY Institute of Technology

Dr. Loan T. Phan

University of New Hampshire

Dr. Karen Quintiliani

California State University, Long Beach

Dr. Angela Reyes

Hunter College

The City University of New York

Dr. Fay Shin

California State University, Long Beach

Dr. Christine Su

College of San Mateo

Dr. Alisia Tran

Arizona State University

Dr. Khatharya Um

University of California, Berkeley

Dr. Kim Tran

University of California, Los Angeles,

Glendale Community College

Dr. Soua Xiong

California State University, Fresno

Dr. Zha Blong Xiong

University of Minnesota
Dr. Sophal Ear

Occidental College

Dr. Jeremy Hein

University of Wisconsin, Eau Claire

Dr. Nancy H. Hornberger

University of Pennsylvania

Dr. Peter Tan Keo

New York University

Dr. Yvonne Kwan

San Jose State University

Dr. Ravy Lao

California State University, Los Angeles

Dr. Stacey Lee

University of Wisconsin, Madison

Dr. Sue Needham

California State University, Dominguez Hills

Dr. Max Niedzwiecki

Daylight Consulting Group

Dr. Clara Park

California State University, Northridge

Dr. Giang Pham

University of Massachusetts Amherst

Dr. Malaphone Phommasa

University of Clifornia Santa Barbara

Dr. Kalyani Rai

University of Wisconsin-Milwaukee

Dr. Cathy J. Schlund-Vials

University of Connecticut, Storrs

Dr. Nancy J. Smith-Hefner

Boston University

Dr. Yer J. Thao

Portland State University

Dr. Monica M. Trieu

Purdue University

Dr. Silvy Un

Saint Paul Public Schools

Dr. Linda Trinh Vo

University of California, Irvine

Dr. Molly Wiebie

The University of Texas at Austin

Dr. Yang Sao Xiong

The University of Wisconsin-Madison 


\section{Doctoral Student Editorial Review Board}

\author{
Diana Chandara \\ University of Minnesota \\ Bao Diep \\ University of Minnesota \\ Nielsen Hul \\ Cornell University \\ Vanessa Na \\ University of California, San Diego \\ Hoa Nha Nguyen \\ Boston College \\ Linda Marie Pheng \\ University of Wisconsin-Madison \\ Mai Vang \\ University of Massachusetts Boston \\ Thong Vang \\ University of Minnesota
}

\author{
Linh Dang \\ University of Rochester \\ Annie BichLoan Duong \\ San Joaquin County Office of Education \\ Dung Minh Mao \\ University of Minnesota \\ Thien-Huong Ninh \\ University of Southern California \\ Khoi Nguyen \\ George Mason University \\ Krissyvan Truong \\ Claremont Graduate University \\ Melissa Vang \\ San Diego State University
}

